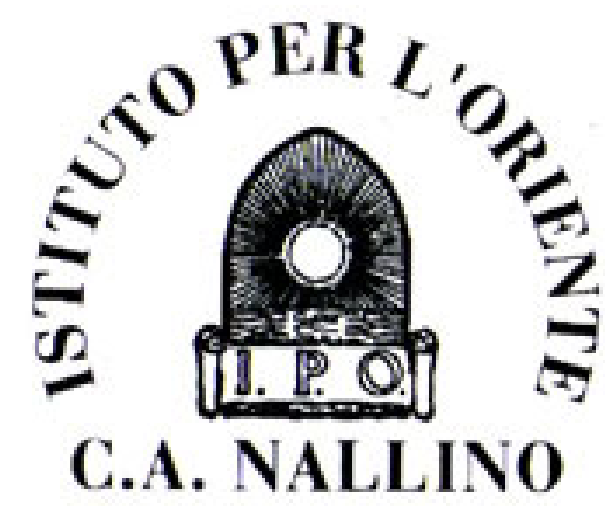

\footnotetext{
"HADĪTH", AUTHORITY AND THE END OF THE WORLD: TRADITIONS IN MODERN MUSLIM APOCALYPTIC LITERATURE

Author(s): DAVID COOK

Reviewed work(s):

Source: Oriente Moderno, Nuova serie, Anno 21 (82), Nr. 1, Hadith in Modern Islam (2002), pp. 31-53

Published by: Istituto per l'Oriente C. A. Nallino

Stable URL: http://www.jstor.org/stable/25817811

Accessed: 04/02/2013 16:32
}

Your use of the JSTOR archive indicates your acceptance of the Terms \& Conditions of Use, available at http://www.jstor.org/page/info/about/policies/terms.jsp

JSTOR is a not-for-profit service that helps scholars, researchers, and students discover, use, and build upon a wide range of content in a trusted digital archive. We use information technology and tools to increase productivity and facilitate new forms of scholarship. For more information about JSTOR, please contact support@jstor.org. 


\section{DAVID COOK}

(UNIVERSITY OF CHICAGO)

\section{HADİTH, AUTHORITY AND THE END OF THE WORLD: TRADITIONS IN MODERN MUSLIM APOCALYPTIC LITERATURE}

\section{Authority and tradition: the questions}

$\mathrm{F}^{\mathrm{ew}}$ would doubt that the hadit literature in Islam is of fundamental importance for the legal and social structure of Islam. From the earliest years of the Muslim community, this literature has been the focal point for the theological, intellectual and cultural battles which have defined Islam. At its core, a badit is either a statement made by the Prophet Muhammad about a given situation or in response to one (or a question), or a pseudo-biographical vignette about some action taken by him and observed by his companions. If one accepts the Muslim presentation of the badit literature, then virtually no aspect of the Prophet's life has gone unrecorded, from the eternally significant to the most (apparently) banal and irrelevant. All of this material has been subjected for the past 1300 years to the minute examination of generations of Muslim scholars, who have interpreted it, written tomes and tomes to explain it and comment upon it, to verify its transmission, and to harmonize its numerous inconsistencies.

The authority of the hadit literature first of all rests upon the person of the prophet Muhammad - his unique and divinely protected life and words - and secondly upon the reliability of generations of Muslim scholars and their ability to transmit from the Prophet's immediate companions until our own times. Most western scholars deny that the hadit literature in the form that we see it today is dependent upon the Prophet Muhammad or reflects his views (which are so varied and mutually contradictory inside the literature that it would be impossible for anybody to say with any certainty what he believed on any given subject). However, Islam is a faith which has always stressed the ability of mutually contradictory views to co-exist in harmony, and has not seen this aspect of the hadit literature as a liability but as an asset, enabling as it does widely differing interpretations of Muslim law to continue without the necessity for anathemas.

During the past 150 years, as Muslims have begun to be aware of Western critiques of the hadit literature, and especially during the past 30 years, there has been a marked acceptance among fundamentalist circles (which has also come to penetrate the larger conservative religious community) that there can be only one truth, and one interpretation of the truth. It is ironic, but this intolerance of other opposing interpretations of Islam has been one of the by-products of Orientalist research. Many fundamentalists have come to harbor some suspicion 
about the hadit literature, as it is patently impossible to find a single truth on the basis of it (even assuming as some do, the use of "authoritative" collections, such as that of al-Buhārī, since the usual method was to record many mutually contradictory traditions). For some, this has meant a return to a strictly Qur'ānic Islam, which would, if actually literally adhered to, denude the faith of a great many of its most distinguished (and distinguishing) traits. This reliance upon a somewhat 'Protestant' methodology would seek to find a given truth in the Qur'ān (often times without reference to traditional commentary), and use some parts of the hadit literature which are most closely in line with the chosen interpretation and ignore the rest. For others, this attitude has lead to a search for alternative sources of authority. This last idea is highly problematic in Islam. While no one has identified exactly what the sources of authority are for non-legal traditions, it has never been customary to base a subject of crucial importance upon a source of authority which does not include the Prophet Muhammad or one of his close companions as the fount of the teaching. For peripheral issues, at certain times material ascribed to previous prophets (such as Solomon or Jesus) has been accepted, and sometimes that of later revered Muslim figures has been as well, for those groups in Islam who revere them.

However, to seek beyond the pale of Islam for sources of authority is questionable, and very bold. Never has the community of Islam previously rewarded such boldness with general acceptance. It is a sign of how deeply troubled modern Islam sees itself, and how desperate it is in its fifteenth century, that an important set of beliefs in some cases has fallen under the sway of outside influences, and moreover has been accepted despite this fact. This set of beliefs is Muslim apocalyptic and the beliefs connected with the end of the world. ${ }^{1}$ In this paper we will examine the beliefs, first of all in their classical setting, and then in their modern interpretations. Most of the paper, however, will deal with the question of the relative authority of the two foreign influences upon Muslim apocalyptic literature: the anti-Semitic conspiracy theory, and the Biblical evangelical apocalyptic popularized in the English speaking world during the past 30 years.

1 - See, e $\rightarrow$ Wilferd Madelung, "Aabdallah b. al-Zubayr and the Mahdi”, Joumal of Near Eastern Studies, 40 (1981), p. 291-306; Idem, "Apocalyptic prophecies in Hims during the

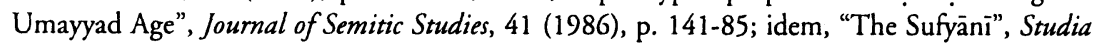
Islamica, 63 (1986), p. 5-48; Suleiman Bashear, "Early Muslim Apocalyptic Materials", Journal of the Royal Asiatic Society, 1991, p. 173-207; idem, "Muslim Apocalypses", Israel Oriental Studies, 13 (1993), p. 75-99; Michael Cook, "Eschatology, History and the Dating of Traditions", Princeton Papers in Near Eastern Studies, 1 (1992), p. 23-48; idem, "The Heraclian Dynasty in Muslim Eschatology", al-Qantara, 13 (1992), p. 3. $\leadsto$ idem, "An early Islamic apocalyptic chronicle", Journal of Near Eastern Studies, 52 (1993), p. 25-29; Lawrence Conrad, "Portents of the Hour", forthcoming in Der Islam; and my "Muslim Apocalyptic and jihäa", Jerusalem Studies in Arabic and Islam, 20 (1996), p. 66-104; idem, "Moral Apocalyptic in Islam", Studia Islamica, 86 (1997), p. 37-69 among numerous studies. 


\section{Apocalyptic beliefs in Islam}

The basis of the authority of the apocalyptist is the assumed ability of the Prophet Muhammad (never claimed in his own lifetime) to see the entire future. "God has lifted the world up for me [Muhammad] - I am looking at it and at what will happen in it until the Day of Resurrection just as I am looking at my hand here - a revelation ${ }^{2}$ from God, which He vouchsafed [to me], just as $\mathrm{He}$ vouchsafed it to the prophets before him." 3 Another tradition reads: "...then he [Muhammad] spoke to us until the sun went down. He did not leave out anything from what is to happen until the Day of Resurrection..." In brief, we will summarize what these events are to be.

The apocalyptic literature that has sprouted up as a result of this tradition, and the world-view which supports it, describes the world (from a Muslim point of view) as it nears the final, anticipated end. It concentrates on four aspects of this process. The first of these is the phenomenal conquests of the first century (632-732), which ended with the Muslim empire controlling most of the classical world, from France, Spain, North Africa and Sicily in the west to Central Asia and India in the east. Only the ancient Christian empire of the Byzantines (what is now Turkey, Greece, the Balkans, and part of Italy) stood between them and ultimate victory. So it is hardly surprising that the sub-genre of conquest apocalyptic is concerned with the final, end-times fall of Constantinople and the collapse of the Byzantine empire. Other material appears, concerning the Turks, the Indians and the Chinese, but these were peripheral to the Muslim understanding of the nature of their mission. When this literature was first circulated this understanding was still dominated by the idea of the classical world of the Roman Empire and Persia. However, unlikely though it might have been at the time, the Byzantine empire was fated to outlive that of the first Muslim Arabs, a fact which brought home the great disconfirmation of their apocalyptic conquest hopes. This material continued to be useful to the Muslims as a whole in their age-long struggle with the Byzantines, and possibly assisted in the propaganda of the Turks, who ultimately succeeded where the Arabs failed.

Another manifestation of apocalyptic literature was involved with the creation (or in some cases adoption) of demonic or semi-demonic figures who were designed to test and try the Muslim community with the ultimate aim of its purification. For while apocalyptic groups recognized the evil of their society and railed against it at every available opportunity, they required a focus for their loathing. This focus, for Sunni Muslims, was the figure called the Dağgàl, the Antichrist. He represents everything which they excoriate, and all of the tempta-

2 - Read jalayan or jilliyan - this is the Syriac word gellyona, which is used for the "Apocalypse of St. John" (see G. Graf, Verzeichnis arabischer Kirchlicher Termini [CSCO, vol. 147, Louvain, 1954], p. 35).

3 - Nu 'aym b. Ḥammād, Kitäb al-fitan, ed. Suhayl Zakkār, Bayrūt, Där al-Fikr, 1993, p. 13.

4 - Ibid. Both of these traditions are regularly cited in modern apocalyptic books; see, e.g., 'Abd al-Wahhāb 'Abd al-Salām Ṭawilah, al-Masiḥ al-muntazar wa nihāyat al-' calam, al-Qāhirah, Dār al-Salām, 1999, p. 6-7. 
tions which they must overcome. For they must face and master his temptations, both personally and as a group. He is placed against the figure of Jesus, who fights, defeats and slays him, thereby ending the period in which Muslims must be tempted by this world. For the $\widehat{S}_{i}{ }^{-} i$ Muslim a figure called the Sufyāni, who is something of a caricature of the evil Muslim ruler, fulfills the same function. With these cycles of saga, we move out of history and into a sort of end-times hiatus in which both supernatural good and evil figures play roles in the world.

Literary messianic expectations also receive a good deal of attention in the apocalyptic material. The messiah, called either the Mahdi or the Qã'im, is seen as a God-empowered man, through whom God will reestablish His rule over the earth and overcome human evil (not the Dağğăl, for example, since he is virtually a demon). It is he who will bring true justice into this world and right the wrongs of history which have been allowed to fester and grow because of the frustration and impotence of true Muslims. The Mahdi figure is the culmination of history - the one point in time during which we can say that there will be justice reigning on earth. "If there were only one day left in the world, God would lengthen it so to send a man from my [Muhammad's] family who would fill the world with justice and righteousness, just as it has been filled with injustice and unrighteousness.". 5 This tradition, which is one of the most ubiquitous in all of the apocalyptic literature, makes an incredibly valuable promise to the believer. There will be justice in this world, even if it is only for one day. God has promised it, and $\mathrm{He}$ will send someone from the venerated family of the Prophet Muhammad, who will function as His agent and enforce His absolute justice. The true apocalyptist, therefore, is focused on this world, not on the next. Justice must occur, even if it for a brief time, before God's ultimate, final justice at the Day of Judgment. For this he is willing to sacrifice anything, everything.

It should be noted, however, that one of the distinctive features of the apocalyptic landscape is both its very cyclicality and the fact that the Day of Resurrection is never quite reached inside the traditions. This plays a part, and indeed a very important one, in other genres of Muslim tradition and literature, but this final goal is never reached inside apocalyptic traditions. It is like a gigantic cliff overhanging the apocalyptic plain upon which the Muslim trudges through the various trials and tribulations of the Dağğăl and the apocalyptic wars and enjoys the rule of the messianic period. It overshadows the whole of the action, yet is not corporeally present.

The apocalyptic vision would not be complete without the moral apocalypse in which the ideal society is delineated, mostly in a negative form. ${ }^{6}$ Since the truly Muslim society is the opposite of the one in which we presently exist, it exists as sort of a shadow or a counter-society. However, the material in this sort of apocalypse is the weapon by which the apocalyptist enforces his will in society. To this end he relies on a very common world-view prevalent throughout history in religious cultures: namely that the past is better than the present, and

5 - al-Hindī, Kanz al-‘ ummäl, ed. Bakrī Hayyānī, Bayrūt, Mu’assasat al-Risälah, 1987, XIV, p. 267 (no. 38,676).

6 - See my "Moral Apocalyptic". 
that the future previous to the messianic age is the worst of all. Therefore, if the apocalyptist can persuade his audience that they are actually in the end-times, he is in the clear, because the belief that this period will be representative of all of the collective evil that humanity can spew out is very well-rooted. Since this belief is in fact fallacious, as any historian knows, what the apocalyptist is actually attacking are characteristics, albeit negative for the most part, common to all humanity for as long as history has been recorded. Since this material is always contemporary, the apocalyptist has it very easy - he can always point out that the period in which he is living has been predicted by past prophecies, and he is frequently believed.

\section{Modern apocalyptic writings}

Muslim apocalyptic writing, therefore, has a powerful and coherent tradition available descriptive of the end of the world. Unfortunately, this picture is for the most part only relevant to the political situation of the first century of Islam, and in numerous ways does not reflect present realities of our own time. It is the nature of the hadit literature to favor a conservative, non-interpretative function; however, this is simply not sufficient in the world in which we live. Apocalyptic (and many other genres of hadit) must be made relevant. Against all the grain of Muslim history, during the past 15-20 years there has been an attempt to do so. Factually speaking, until the recent past apocalyptic literature in Islam has been kept simply to the purely descriptive. This means that a standard book such as that of al-Šawkāni (d. 1834), al-Tawdīh bi-mā tawätara fi al-muntazar wa lDağgal wa l-Masih, written during the Napoleonic invasion of Egypt (which the author witnessed), includes absolutely no mention of the great events which took place during the author's lifetime. The traditions about the end of the world - and one has to infer this, but it seems rational that the purpose of the book is to say that the world is about to end, or that the invasions are at least precursors of the end - are stated without any explanation or elucidation on the part of the writer whatsoever. His function was merely to transmit; it was entirely up to the reader to interpret the traditions and note their relevance to events occurring around him.

This very passive and assumptive approach to apocalyptic was common among the religious leadership, both because it was favored by the transmitters of the hadit literature, and more especially because of the politically and religiously explosive nature of apocalyptic in particular. They most certainly did not want to provoke reactions on the part of their audience which they could not control. One would expect that the beginnings of colonial rule and the exposure to the methods of Christian apocalyptic writing (which were known to Muslims, who had to debate them frequently) would have brought a sea-change to this passivity. However, this is not the case - both in India and in Egypt (the two major centers of apocalyptic writing during the colonial period) the methods remained the same throughout this time. Comparing Habibulläh al-Šanqaytī 
(writing in 1926 in Egypt) ${ }^{7}$ or al-Kašminī (d. 1933 in India) ${ }^{8}$ with Ibn Katīr or other classical writers reveals no changes. In the wake of the Six Day War of June 1967 with Israel, during the course of which the Arabs were decisively defeated, this attitude changed, albeit gradually at first.

For some time previous to this date conspiracy literature had been making headway in Arabic, and by the 1950s had come to be generally accepted as an accurate rendition of political events. Mainstays of the conspiratorial antiSemitic world-view such as The Protocols of the Elders of Zion, Count CherepSpiridovich's The Secret World Government or 'the Hidden Hand' and William Guy Carr's Pawns in the Game ${ }^{10}$ and other literature of this sort had been translated into Arabic by this time, and were frequently parroted by political leaders for the benefit of those unable to read them (or sometimes for those unable to grasp the ideas and turgid writing style of these polemicists). However, there is no evidence that these works had any influence upon the purely religious Muslim world. The astonishing event of the Six Day War required an entirely different mind-set, and it became obvious that previously accepted frameworks were obsolete. The Jew was victorious not because of superior technology or a more disciplined army or even because of a more coherent and unified ideology, but because he was the agent or even the avatar of the Antichrist.

As noted previously, the idea of the Antichrist (the Dăğgall) undoubtedly entered into Islam from Christianity, and most of the Dağğăl stories are direct translations of Christian material, and are sometimes even inexplicable without knowledge of their ultimate background. The Dağḡal was not the most popular figure in the fantasy land of Muslim apocalyptic stories during classical times. It is rare to find books dedicated to him, or to find about him the extensive material which was constantly flowing back and forth between opposing Muslim parties as to the identity of the Mahdi. However, it is clear, as noted above, that the Dağğāl is a Jew (again, an element taken directly from Christian sources), and although clearly classical Muslim apocalyptists had not the slightest anticipation of the foundation of a Jewish state some 1400 years in the future, they did see the Jews as a malevolent force behind the scenes. Jews do not play a prominent role in classical Muslim apocalyptic, but when they do appear, it is as manipula-

7 - Habibullāh al-Šanqaytī, al-Ǧawāb al-muqnic al-muharrar fi radd man țágä wa tağabbara bi-dác wa annahu 'İ̀à aw al-Mahdì al-muntazar, al-Qāhirah, al-Manār, 1926.

8 - al-Kašmīī, al-Tasrị̣ bi-mā tawātara fi nuzül al-masĭh, Bayrūt, Dār al-Kitāb al-'Ilmiyyah, 1992 - this volume was a private sourcebook designed to provide Muslims with answers to the claims of the Ahmadis.

9 - Who actually quotes the Qur'ān to say "Whoever is a friend of a Jew, belongs to them, becomes one of them. GOD cannot tolerate this mean people. The Jews have wandered away from divine religion (given by Moses). They are usurpers. You must not relent in your work which must show up Jewish deceit". Count Cherep-Spiridovich, The Secret World Government, New York, The Anti-Bolshevist Publishing Association, 1926, p. 126, which appears to be a very loose paraphrase of Qur'ān 5:51 (but he does not mention that the Christians are not supposed to be taken as friends either).

10 - William Guy Carr, Ahğăr ' alà ruq at al-šantrağ, trans. Sa 'īd Ğazā’irlì, Bayrūt, Dār alNafä'is, 1975. 
tors and plotters. This conception fits in with the interpretation many Muslims wished to give to the Six Day War, and eased the acceptance of anti-Semitic conspiracy material into the general audience. More specific intellectual problems stemming from this acceptance will be dealt with below.

With the adoption of the anti-Semitic conspiracy material the modern Muslim apocalyptist had a conceptual framework with which he could work, and one which explained a great number of otherwise inexplicable and frustrating events taking place in the world around him. However, what he then lacked was positive proof for the whole scheme. The anti-Semitic conspiracy theory has deep roots within Western religious and secular culture, and ultimately finds support (albeit indirectly) in the New Testament, with the first Christians' frustration at the unwillingness of the Jews to accept Jesus as messiah. When it became apparent to all that the Jews (leaving aside individuals who passed out of the Jewish people) were unwilling to take this step, and that Jesus did not appear suddenly to judge the evil world (as is promised in Matt. 16:28), many Christian hopes and aspirations were put off into the eschatological future to be fulfilled at an indefinite date. Christians developed in the Book of Revelation (and in their interpretations of many other Biblical books, and the apocalypses which spun off these sources) a powerful picture of a scenario which would be so dynamic that even the stubborn Jews would turn to Jesus as a result of experiencing it. Part of this scenario required the evil (at least in the Christian view) to be excised from the Jewish people, and manifested in a personality which was so antithetical to Christ as to be an "Anti-Christ" in all ways. Although it is not stated, it seems clear that this figure would be something of a sacrificial lamb (somewhat like the Yom Kippur scape-goat) who would be the focus of all the negative qualities present in the Jewish people, and could be totally loathed because of this.

This figure would then pay for the collective rejection on the part of the Jewish people of Jesus, and be sent to the Lake of Fire, while the balance of the Jews would be saved and accepted. Christians could not absolutely demonize the Jews because of their dependence upon them for the foundations of the Christian faith, and the reasons for the appearance of the messiah. Through the Antichrist however, the Jews' rejection of Christ could be safely hated and demonized, and eventually expunged from God's chosen people. While the Muslims accepted this framework, they felt no necessity for dependence upon the Jews. Being far removed from the Biblical events, and in any case possessed of a revelation separate from (although in the same general tradition with) the Bible, they could safely excoriate the Jews without any repercussions rebounding upon the foundations of their faith. By the time Islam became intellectually independent there was a considerable divide between the Biblical Jewish people, and the contemporaneous one. Only recently has that divide been broken down once more. ${ }^{11}$

11 - See my "Banu Isra'il to the State of Israel: the changing exegesis of Qur'ān 17:4-8" forthcoming. 


\section{The problem of authority and relevance: the anti-Semitic conspiracy theory}

Muslim apocalyptists are very much aware of their perilous and marginal situation, and have thus sought to find other sources to strengthen their case. In the following sections, we will examine three different apocalyptic writers (although others will be noted in the footnotes) for their use of hadit, and how it relates to non-Muslim material, such as Biblical and conspiracy-anti-Semitic material. Of the three writers, two are among the most prominent in the field. The first is $\mathrm{Sa}{ }^{\mathrm{i}} \mathrm{id}$ Ayyüb, who pioneered the synthesis of the above materials in the middle 1980s. His first book, al-Masĭ al-Dağğal (1987) has been the most influential published thus far, ${ }^{12}$ and has set the tone for most of the publications in the field. The second writer, Muhammad 'İsà Dä'ūd, has concentrated on paranormal manifestations of apocalyptic beliefs, and has connected them successfully to the Muslim apocalyptic scenario through the common link of antiSemitism. However, the book chosen for analysis, al-Mahdi al-muntazar calà alabwäb does not emphasize the paranormal. ${ }^{13}$ Both of these writers are violent and blood-thirsty anti-Semites, and their material is extremely graphic. The third writer, Amin Muhammad Ğamāl al-Din, is a man who has made a serious attempt to date the end of the world from a Muslim point of view. His three pamphlets have stirred up a considerable controversy in Muslim religious circles. ${ }^{14}$

All three of these writers have a very set scenario in mind. The end is imminent, and the portents have already been fulfilled. Ğamal al-Din, as a matter of fact, devotes an entire book, al-Qawl al-mubin fi al-ašrät al-sugrà li-yawm alQiyamah, to proving that they have already been fulfilled. He lists off 79 of them (with an additional half-dozen which he says are too indistinct to prove either way). For the other two writers, the defining features of the end times are the alleged total Jewish domination of the world, and the world-wide concerted effort to wipe out Islam (it goes without saying that the vast majority of the beliefs cited from Ayyūb and $\mathrm{Da}^{-} \mathrm{u} \overline{\mathrm{u}} \mathrm{d}$ are paranoid and have no basis in reality, but will simply be presented according to their world-view).

Ayyüb, for example, makes a maximum effort to present us with a lesson in history: the anti-Semitic conspiracy theory. Jews have infiltrated and corrupted Christianity from within to suit their purposes. ${ }^{15} \mathrm{He}$ spends a great deal of time with this issue. For example, the apostle Paul is a secret agent sent by the Jews to

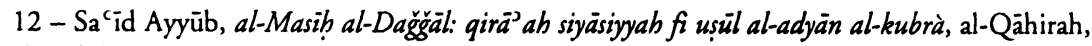
al-Fath li-l-A 'läm al-'Arabì, 1987.

13 - Muhammad 'īsà Dā'ūd, al-Mahdì al-muntazar 'alà al-abwäb, al-Qāhirah, al-Maktabah al-'Arabiyyah li-l-Tịä' ${ }^{\circ}$ ah wa l-Našr, 1997.

14 - Amin Muhammad Ğamāl al-Dīn, 'Umr ummat al-Isläm wa qurb zubūr al-Mabdī ' alayhi al-saläm, al-Qāhirah, al-Maktabah al-Tawfiqiyyah, 1996; al-Qawl al-mubin fi al-ašrät al-suğrà li-Yawm al-din, al-Qāhirah, al-Maktabah al-Tawfiqiyyah, prob. 1997; Radd al-sihäm 'an kitäb 'umr ummat al-Isläm wa qurb zuhür al-Mahdī 'alayhi al-saläm, al-Qähirah, al-Maktabah alTawfiqiyyah, prob. 1998 or 1999.

15 - The breadth and depth of this conspiracy can only be compared to the fictional one in Umberto Eco's Foucault's Pendulum, though clearly Ayyūb really believes what he writes. 
corrupt Christianity, ${ }^{16}$ the emperor Constantine's embrace of Christianity is an example of "the hidden hand" of the Jews, ${ }^{17}$ and the Crusades were brought about by the efforts of the medieval popes, who were all themselves Jewish. ${ }^{18}$ Martin Luther, who was a fanatical follower of Paul, brought Christianity even closer to the Dağğal because of his pro-Jewish tendencies (!), ${ }^{19}$ and when the Protestants fled Europe to America, they brought with them a subservience to the Jews. ${ }^{20}$ Napoleon Bonaparte was also a Jewish agent. ${ }^{21}$ Much attention is devoted to the Jewish connections of Communism, and how this is designed to destroy Islam, ${ }^{22}$ and to the World Wars (I and II) which were arranged by them as well. ${ }^{23}$ This leads him to state baldly that "all of history bears witness that the United States of America, which has been occupied in all areas by the beliefs of the Dağğal is now the chief enemy of Islam in every place." ${ }^{24} \mathrm{He}$ also rebukes Muslims harshly for "drinking from the rivers of the Jews and Christians - because of their gulping a humiliating disgrace has ensued" 25 (he seems immune to the fact that he, too, draws upon western thought to a large extent).

One might legitimately ask: where in all of this rendition is the badit? and what benefit can a Muslim hope to derive from it? Ayyüb's style is such that for him the foreign material is presented first, and then the hadit which he can use to support his case. Whatever suits his purpose, he quotes, whether in context or out of it. For example, quotations appear from Jewish (Joshua Prawer, Yitzhak Rabin, Abba Eban, Hermann Kahn), Christian (John Wesley, George Pakhoury, Jean Dixon), and historical-philosophical sources (Will Durant, Bertrand Russell, Jean-Paul Sartre and others), without any attempt to make any division between them, and generally twisting their words in order to reach the conclusions he seeks. However, much of his material comes from conspiracy theorists. ${ }^{26} \mathrm{He}$ does cite hadit when he gets to the point where he has to deal with the actual

16 - Ayyūb, p. 42f.; although Ayyūb is ignorant of it, this accusation was already common in classical Islam: P.S. van Koningsveld, "The Islamic image of Paul and the Gospel of Barnabas", Jerusalem Studies in Arabic and Islam, 20 (1996), p. 200-229.

17 - Ayyüb, p. 56.

18 - Ayyūb, p. 183f.; and Fā' iq Muhammad Dā'ūd, al-Umür al- ${ }^{c} i z \bar{a} m$, n.p., 1999, p. 27-28.

19 - Ayyūb, p. 59f.; and note that Hišām Kamāl 'Abd al-Hamìd, Haläk wa damär Amrikāa almuntazar, al-Qāhirah, Dār al-Bašìr, 1996, p. 23 makes the assertion that John Calvin was originally a Jew named Cohen who changed his name upon coming to Geneva.

20 - Ayyüb, p. 61.

21 - Ibid., p. 62.

22 - Ibid., p. $118 \mathrm{f}$.

23 - Ibid., p. 183.

24 - Ibid., p. 64.

25 - Ibid., p. 130.

26 - William Guy Carr, Pawns in the Game (trans. into Arabic as Ab̆ğär 'alà ruqc at šantrağ) is frequently quoted and is very influential in Muslim apocalyptic literature, and usually provides them with the veneer of historical learning; in addition to various less savory materials such as the Protocols of the Elders of Zion (e.g., Ayyūb, p. 114). 
events of the end-times; until then it is all western history and the anti-Semitic conspiracy.

According to Ayyüb's interpretation, the Battle of Armageddon will be fought by a coalition of western Christians, who will be lead by the Antichrist (a Jew), in the traditional location, in the Valley of Jezreel against a coalition of Muslims. For this he manages to find support in Muslim sources by twisting the texts somewhat. ${ }^{27}$ But fundamentally this works not because the Muslim sources would indicate this particular scenario, but simply because Ayyüb cites them in such a selective manner that in the end they read just as he would want them to. But his base idea is that the battle which will be fought is the Battle of Armageddon, and not the traditional Muslim story about what the Dağğăl will do. He has overlaid the Christian framework upon the Muslim sources (citing them only briefly), and made the Muslims win. A great deal of detail appears about this war, and the process by which the Antichrist will take over the West. ${ }^{28}$ The Muslims will prevail, and go on to conquer Western Europe (remembering that he wrote before the fall of Communism). At that point, apparently, the Antichrist, who will not be slain in the battle, will reappear in the homelands of the Muslims, so they will be required to return to fight him. ${ }^{29}$

The Dağgal will not be slain in the Battle of Armageddon and will reappear in the Muslim lands with a mammoth army of Jews and their followers. He will advance from eastern Iran to the Persian Gulf and occupy Mecca and Medina. Israel will join him (despite its destruction during the previous battles) and the Muslims will flee to northern Syria, where they will be besieged by the Dağğăl and his followers. These will be defeated by Jesus Christ, who will return to earth as a Muslim and there will be a slaughter of the Jews.

"Then the Dajjal and his supporters are placed in a press, like the press into which the pride of the men of Armageddon disappeared during the great apocalyptic war... Then the last battle will occur, when the results of age-long deceit will fall into oblivion. I mean by this the problem of the heritage of Israel... this problem from which the belief in the godhood of the messiah of Israel stems, and all of the economic and political ideologies which cause the world to be always at war. Because of this [problem] chains and fetters have been placed upon the Islamic world for such a long time". ${ }^{30}$

Ayyūb is really quite blood-thirsty and somewhat sadistic in his delight at the defeat of the Jews. As Jesus and the victorious Muslims advance upon Jerusalem, he has this to say:

\footnotetext{
27 - Ayyub, p. $281 f$.

28 - Part of this is achieved by citing Henry Kissinger (an almost demonic figure in many Muslim apocalyptic scenarios). See Șifr b. 'Abd al-Raḥmän al-Huwayli, Wacd Kissinğir wa lahdāf al-Amrikiyyā fi l-Halïğ, Dallas, Texas, Mu’assasat al-Kitāb al-Islāmī, 1991, passim; and Ronald Reagan, whom Ayyüb considers to have been an agent of the Dağǧăl (p. 166-167).

29 - Ayyūb, p. 193 f.

30 - Ibid., p. 283-284.
} 
"Rejoice, $\mathrm{O}$ daughter of Jerusalem! ${ }^{31}$ The Jew in the courtyard will be like a broken man, prepared for death in any form. The Christian on the crossroads will find that his 'messiah' [the Dağǧal] has collapsed... then the 'Prince of Peace' [the Dağğăl] will die. Jerusalem was never made for the Jews. Weep, $O$ daughter of Jerusalem behind whatever wall you please! The Dictator will die and your destiny will be in the hands of fate". ${ }^{32}$

He then cites one of the anti-Semitic traditions from classical apocalyptic:

"As the Prophet [Muhammad] said: His - the Dağğal's - followers will retreat, and on that day there will be nothing which will conceal them, so that the stone will say: O Believer! here is an infidel! And the Jew will conceal himself behind stones and trees, and the stones and the trees will say: 'O Muslim! O servant of God! here is a Jew behind me, come and kill him...' All of the books will be burnt at the end of the road. Those who sucked at deceit, spying and hypocrisy will be burnt beneath the feet of the prophet of God, Jesus, and the army of Islam: the agents, the followers, the collaborators, the thinkers, the observers, the supporters, the fans, the mob, the dogs, the wolves, the monkeys, and the pigs. ${ }^{33}$ They will be trampled under after the dawn... [there will be] a sound like the sound of a groan, but it will not avail, because his [the Dağğăl's] followers believed in him even before they saw him". 34

Further removed from Ayyüb's history lesson and his conspiracy theory is Amin Muhammad Ğamāl al-Dīn's first book 'Umr ummat al-Isläm. He is steeped in the world of al-Azhar and traditional hadit interpretation, and knows what the conservative opposition is likely to say to his innovation of attempting to date the end of the world. Therefore, in his view it is not the issue of European history or deciding which Popes were Jews that is the critical deciding factor. $\mathrm{He}$ spends a worthy amount of time focusing on the so-called lesser signs of the Hour (the political, moral and social events preparatory to the end of the world). ${ }^{35}$ There are those events, such as the taking of Jerusalem, the splitting of the moon (Qur'an 54:1), the appearance of plagues and so forth which will proceed the distinctive tribulations associated with the end of the world. In the interpreta-

31 - A parody of the verses in Zechariah 2:10, 9:9.

32 - Ayyūb, p. 286-287.

33 - Usually "monkeys" are Jews and "pigs" are Christians in Muslim religious literature.

34 - Ayyüb, p. 286-288. The tradition about the rocks and the trees and the killing of the Jews is frequently cited in Muslim apocalyptic sources, and even conservatives tend to add in a note of hope about its fulfillment in the near future: 'Izz al-Din Husayn al-Šayh, Ašrăt al-Sä́c ah alșugrà̀ wa l-kubrà, Bayrūt, Dār al-Kutub al-'Ilmiyyah, 1993, p. 11; Mușțâ 'Abd al-Qādir 'Atā̄', al-Masīh 'İ̀à wa nuzüluhu äbir al-zamān wa qatluhu al-Dağğäl, al-Qāhirah, Maktabat al-Turāt al-Islämi, 1986, p. 23; and it appears in the Hamās Covenant (see trans. in Jourmal of Palestine Studies, 22 [1993], p. 122-134).

35 - He deals with the lesser signs in 'Umr ummat al-Islä, p. 29-34 in a shortened form, in addition to devoting the volume al-Qawl al-mubin to them. 
tion of each of these he, unlike his conservative predecessors, is very careful to point out relevant modern facts and does not suffice himself with irrelevant comments about volcanic explosions which happened in Aden in 1256, or leave signs such as the appearance of the Dağğal seven years after the taking of Constantinople (historically in 1453) unexplained. ${ }^{36}$

For example, when speaking about the taking of Jerusalem, he has the following comments to make (since of course he is aware that it is not under the control of the Muslims at the present time):

"[after giving an accurate rendition of the history, including the fact that Muslims gave the city of Jerusalem back to the Crusaders twice]... from this we learn that Jerusalem is not a Palestinian issue nor an Arab nationalist issue, but only a religious issue with relation to Muslims and Jews and Crusaders. And for this we see that the Jews in these days - from years past - are making every effort to Judaize Jerusalem, and even attempting to destroy al-Aqșà Mosque so that they can build Solomon's Temple on its place, claiming that they will offer up a burnt offering on it in accordance with their alleged Torah beliefs. The rites will be performed by the one who they claim is their messiah and redeemer, the Dağğal, together with the chief priest of the Jews". ${ }^{37}$

Of course, his use of modern examples does not merely rely on the anti-Semitic conspiracy theory. Frequently he shows his shock at the loose moral standards among Muslim youth of today; for example when dealing with the appearance of sexual promiscuity, he cites the reason for this being French law adopted by Arab (Muslim) states which allows consensual sexual relations between adults. He says that things have gotten to the point where when an imam preached against this, one of the young men in the audience got up and said "Why did God prohibit fornication - isn't it just like marriage?" 38

However, he, like Ayyüb, accepts the anti-Semitic conspiracy theory as part of the reality through which the end time traditions should be interpreted. The principal difference between the two is that Ğamäl al-Din is far more cautious, and is very careful to make sure that everything happens in the order given in the hadit literature. With him, the scenario is dictated by the traditional Muslim view, and not by the Christian evangelical view of events. A good example of this is the fighting of the Jews.

"For the Muslims' fighting the Jews when they will hide behind the rocks and the trees will happen after two signs of the greater signs of the Hour: the Dağğal, and the descent of Jesus, and there is no dis-

36 - Incredibly, conservatives still do not appreciate that Constantinople has been conquered and use this volcanic explosion as a sign of the end, not seeing that it had worn out its welcome already in the Middle Ages (just as it is no longer possible to speak about the Mongols being Gog and Magog): al-Šayh, Ašrät al-Sǟah, p. 21-22, 61-63.

37 - Ğamāl al-Din, al-Qawl al-mubin, p. 19.

38 - Ibid., p. 31 . 
agreement about this originally! and I should add that the lack of appearance of this fighting as part of the greater signs of the Hour does not necessarily mean that it is to be included among the lesser signs of the Hour, as some have understood it, no!! ${ }^{39}$ But there are many events without number then, and when they occur at that time the greater signs of the Hour will occur". 40

This, of course, should not be taken to mean that he is against the scenario of the fighting of the Jews, just that he is concerned that it be put in its proper place. This place is after the Battle of Armageddon.

"[speaking about the Fifth War] In a more exact sense, the fighting of a third of the Jews, since two-thirds of the Jews will have perished in the Battle of Armageddon to such a degree that the Jews that are left will need seven months to bury all of the dead in that battle. [citing Ezekiel 39:12 to prove this] ${ }^{41}$ And then two-thirds of the Jews will perish in the Battle of Armageddon, and the Muslims will rule the third remaining under the leadership of the Mahdi, and this will be after the Muslims' conquest of Constantinople and the appearance of the cursed Dağğăl, who is the king of the Jews. The explanation of this is that the Jews are expecting their messiah, their redeemer or their genius king who will redeem them from these corrupt peoples those other than the Jews of the earth's inhabitants - just like they think, and they believe that his appearance will happen previous to the year 2000 ... So they will hide from the Muslims behind the rocks and trees, but the rocks and trees will give them no respite and will point them out and will denounce them. Just as if they shouted because of the smell of their purrid infidelity, and their undeserved murder of the prophets, and the offensive smell of their hands stained with the blood of innocents, children, old men and women... so the land will be purified from their evil, their cunning, and the stone and tree will speak-- which will not be strange during this time of wonders when the Dağğăl appears and Jesus descends, and Yāğŭğ and Măğŭğ [Gog and Magog] appear against the people, and the entire earth prepares for the last moment". ${ }^{42}$

As one can see, Ğamāl al-Dīn has prepared an entire scenario around the tradition of the "rocks and the trees", as it is quaintly called by Muslim apocalyptists, and merely ensures that we do not take it out of its proper context.

39 - Here he is clearly polemicizing with the political use of the tradition of fighting the Jews. The distinction is an important one: if the "fighting of the Jews" is included among the lesser signs of the Hour, then it is just another political event which can occur previous to the supernatural events of the end time. But if it is pushed into the eschatological future, then it can only occur as part of the general Muslim war against someone who is known to be the Dağgall. 40 - Ğamāl al-Din, 'Umr ummat al-Isläm, p. 12-13.

41 - This tradition already passed into classical Muslim apocalyptic although he does not seem to be aware of it: Ibn Māğah, Sunan, Bayrūt, Dār al-Fikr, n.d., Il, p. 1359 (no. 4,076).

42 - Ğamāl al-Dīn, ' Umr ummat al-Isläm, p. 76-77. 
Like other apocalyptists, Ğamāl al-Din is desperate to find new sources to cite for his theories. Since the basic idea of his book is that the end of the world can be dated, and this approach has not been one favored by Muslim apocalyptic tradition in the past, he has sought sources further afield. For example, in the middle of his book, as he comes close to the crux, we find that he cites such well-known authorities as Richard Nixon saying "by the year 1999 we will have completed our complete domination over the world." 43 Pat Robertson, Billy Graham, Hal Lindsey, Jerry Falwell and several Arab Christian apocalyptic writers are also featured, all saying that the world is about to end in the year 2000. It is only fortified by this dose of courage from foreign sources that he goes about the process of dating the end using the Muslim sources. ${ }^{44}$

Muhammad 'İsà Dā'ūd's book al-Mahdì al-muntazar features a different scenario than either Ayyūb or Ğamāl al-Dīn. It is a very readable volume, filled with fast-paced action (in that, very similar to Ayyüb). However, he does not refight the battles which Ayyüb has already fought. He largely accepts the antiSemitic conspiracy theory as being the most decisive factor in explaining world politics, and does not spend much time on this issue. Although he is violently anti-Semitic, and very insulting to anybody who is not Muslim, his principal point in the book is to search out new sources of knowledge which can help predict the future. In this he actually goes back to early hadit sources, in addition to Coptic, Jewish and early Christian material. In doing this he does not ignore the classical Muslim sources, he merely sees them in light of the new material. One can easily see his western orientation in the fact that he is fascinated by all things new (even if they are basically old sources). Fundamentally, his problem in writing a book on the Mahdi, is that this figure was looked upon with suspicion by a great number of the religious caste in classical Muslim times, who did permit traditions about him to be cited in great numbers (probably because of the political explosiveness of the whole issue). ${ }^{45}$

Therefore, $D \bar{a}^{-} \bar{u} d$ is faced with a paucity of material which will aid him in working with the future events. Some of this is simply supplied by his own imagination and wishful thinking about what a modern Muslim would like to see changed about the world (i.e., that the Muslims would unified, rid themselves of western influences, take control of their own destinies, etc.). However, he solves the problem of sources by concentrating on previously unknown manuscripts. Included in these are the Dead Sea Scrolls, to which he devotes a great deal of space dealing with the twisted history of their publication (including the conspiracy theories involved in that episode, the echoes of which have not yet died down). In the scrolls he finds predictions of the Muslim version of the Antichrist, Jesus who will fight and kill him, and the Mahdi. ${ }^{46}$ However, his

43 - Ğamäl al-Din, ' Umr ummat al-Islam, p. 51-52.

44 - His Muslim critics picked up on this weakness - see Musțafâ Murād, Matā taqūm alSǟah?, al-Qāhirah, al-Maktabat al-Qudsī, 1997.

45 - On this issue, see Muhammad Farīd Hiğāb, al-Mahdi al-muntazar bayna al-c aqidah aldiniyyah wa l-madmūn al-siyāsi, al-Ǧazā'ir, al-Mu'assasah al-Wațaniyyah li-l-Kitāb, 1984.

46-Dā'ūd, p. 90-91, 104, 106-107. 
preferred method is to investigate "new" Islamic manuscripts throughout the world from which he is able to take material which can suit his purposes, which we will deal with below.

$\mathrm{Da}^{\mathrm{a}} \mathrm{u} \mathrm{u}$ does not hesitate to use the anti-Semitic conspiracy theory to flesh out his own ideas, and fighting the Jews is one of the principal goals of his book.

"The beginning of the conquest of the entire world will be the conquest of Egypt, and its receiving the oath of allegiance to the Mahdi. It is strange that the leadership of the Jews in the world would expect the flaring up of a fifth war between the Muslims and the Jews, while we Muslims do not expect one, we are only absolutely certain. Our Islam gives us certainty that this war is coming!! It will be wars!! and it will end with the 'Jew hiding behind rocks and trees and the rock and the tree will say: 'O Muslim, O Servant of God! here is a Jew, come and kill him"',47

Throughout his book, the Mahdi continually fights the entire world, but his real implacable enemies are the Jews who are said to be behind every single one of his opponents. Therefore, we find that the Turks, the North Africans, the Europeans and most especially the Americans are manipulated by the Jews into fighting the Muslim messiah. In the climactic moment of the action, the Jews are finally wiped out and their evil is destroyed forever.

Although the traditions about the Muslims fighting the Jews are not very prominent in classical Muslim apocalyptic literature, they are cited very frequently by modern apocalyptists. In many ways, this comparatively rare tradition (in terms of the overall whole) provides the lifeline Muslims need to digest the vast quantity of anti-Semitic material needed to fuel the scenario. Here the genuine Muslim tradition can give legitimacy to an otherwise obviously foreign version of events and "prove" that it has backing from the hadit. In reality, of course, if a Muslim were to look at the balance of the apocalyptic literature in his heritage, he would find that the emphasis on fighting the Jews is not very great, and was generally played down in classical times. Political circumstances and the general acceptance of this anti-Semitic framework have served to legitimize it and blow it out of proportion.

\section{Biblical material}

Biblical materials have a difficult and questionable place in the Muslim tradition. One of the first criticisms dealt with (or faced after publication) by this new trend in Muslim apocalyptic literature is its heavy dependence upon Biblical citations. Some writers face this problem frankly. Hišam Kamāl 'Abd alHamid says, for example:

"Some have protested with the words: 'It is not permitted that we take from the Torah or the Gospels because of the alteration (tabrif).' This is an incorrect belief, because one who studies the Torah and

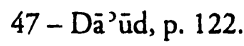


the Gospels well and compares what is brought forth in them with what is brought forth in the Qur' an and the Prophetic tradition will find a complete identity between the two of them in most matters and issues, and will discover that the alteration did not extend to all of the Torah and the Gospels, and there is still within them a great deal over which the hand of alteration did not extend, especially what is connected with the events of the end of time" ${ }^{48}$

It is this 'discovery' (or more accurately, this rationalization) which has enabled Muslim apocalyptists to massively depend upon the Bible for their scenarios.

As a matter of fact, Ayyüb was the first to do this on a massive scale. The bulk of his apocalyptic thought is what can only be characterized as a Muslim reading of the Book of Revelation (though he quotes also from Daniel and Ezekiel). He relies upon the conjunction of Christian (according to his interpretation) and Muslim apocalyptic sources to an extent which was unparalleled in Muslim apocalyptic until his time. However, even though he has rejected the apocalyptic hadit literature as his primary source, he continues to view the Biblical texts through them, and in all cases he reads the cited texts in a very prejudiced manner, and reaches conclusions only made possible through his rejection of everything which does not correspond to his world-view. Ayyüb clearly represents a turning point in Muslim apocalyptic. Previous to him the use of the Bible as a source for apocalyptic scenarios is rare, almost non-existent; after him until the present, a number of the modernist-fundamentalist apocalyptists quote the Bible extensively, even sometimes more than they do the Qur'an. Without Ayyūb this might never have come about.

When Ayyūb begins to deal with the identity of the Mahdī, who will appear after the defeat of the Dağğăl, he goes to Revelation 19:11, where he finds that the name of the messianic figure to be "Faithful" and "True," which happen to be two of the names of Muhammad, ${ }^{49}$ and on this basis proclaims their identity. He further compares the Muslim messianic tradition "The Mahdi is from my [Muhammad's] descendants, from the children of Fātima [Muhammad's daughter]"50 with Rev. 12:1, 5 (specifically with the woman giving birth in this vision) and finds the similarities overwhelming. ${ }^{51}$

Continuing on with Ayyūb's reading of the book of Revelation, he appropriates the Christian symbolism of the New Jerusalem and proclaims it to be Mecca. This is a very problematic point for most other Muslim apocalyptic writers, for the holy cities of Mecca and Medina in Islam have virtually no place in apocalyptic scenarios. As the Hamās leader Bassām Ğirrār says, Islam began in Mecca and will conclude in Jerusalem. ${ }^{52}$ Ğirrār is entirely correct within the

48 - 'Abd al-Hamid, Haläk, p. 5-6; compare also comments in Ğamāl al-Dīn, 'Umr ummat al-Isläm, p. 36.

$49-$ Ayyūb, p. 76.

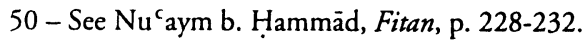

51 - Ayyūb, p. 76-77.

52 - Bassām Ğirrār, Zawäl Isrä’ill: ' ‘àm 2022, Bayrūt, Maktabat al-Biqā̄', 1995, p. 49-50. 
confines of classical apocalyptic and there are very early traditions stating that at the end of time the $\mathrm{Ka}^{\mathrm{C}} \mathrm{bah}$ will come to Jerusalem. The Mahdi (the Muslim messiah) in classical apocalyptic material virtually always has his headquarters in Jerusalem. However, Ayyūb tries to show systematically that the square New Jerusalem of Revelation 21 is the Ka'bah (in Arabic, madinah muka ${ }^{\mathrm{C}}$ bab), ${ }^{53}$ the stones of the foundation (Rev. 21:19-20) are said to be the Black Stone and the River of Life (22:1) is said to be the Well of Zamzam. ${ }^{54}$ Not only that, but the figure of Christ returning in Rev. 19:11 is identified with Muhammad. Therefore according to him, the New Jerusalem is Mecca (he does not understand why Christians have not noticed this already). ${ }^{55}$ In all justice to Ayyūb, this is only a minute fraction of the amazing new interpretations which he has foisted upon Muslim (and Christian) apocalyptic. It is hardly surprising that his book's conclusions have been attacked by several conservatives.

As one might expect, Ğamāl al-Din is far more cautious about the use of Biblical materials, and tries to find justification for it in the hadit literature. However, he sees the apocalyptic awareness of the Christians and the Jews to be one of the signs of the end. For that purpose, he cites a Christian song "O Jesus, Come" as evidence of these beliefs. ${ }^{56}$ But as one reads further into his volume, it becomes more and more clear that although he uses hadit more liberally than either Ayyūb or $D^{-} \bar{a}^{\mathrm{u}} \mathrm{d}$ do, and is less open to biblical material, he has still adopted a large part of their scenario, especially where it relates to the Battle of Armageddon. He takes as his starting point statements by such prominent Christian scholars as Jimmy Swaggart, Jerry Falwell, Scofield, Ronald Reagan and other leading authorities.

Eventually he gets to the point, which is that there is a startling correlation between the hadits about the subject and the Christian material. At this point he cites the famous tradition about the sulb (treaty) to be made between the Muslims and the Christians:
"'You will make a secure treaty (șulh) with the Rum (Byzantines), and you will both, together, raid an enemy behind them, and you will be secure and take spoils, until you will camp in a field with hills (marğ dì tulül). A man from the Rum will stand and lift up the cross and say: 'The cross is victorious!' and a man from the Muslims will stand up to him, and kill him. The Rum will betray [the Muslims] and there will be the apocalyptic battles, and they will gather against you 80 flags, 12,000 [troops] with every flag.' [he says that it is ap- parent that there will be two battles, the first of which is Armaged- don, and the second of which is between the Muslims and the Rum,

53 - Ayyūb, p. 83.

54-Ibid., p. 84-85.

55 - Ibid., p. 79-80.

56 - Ğamäl al-Dīn, 'Umr ummat al-Isläm, p. 20; compare Muhammad al-Bar, al-Masīh almuntazar wa l-ta'älìm al-Talmüd, Ğiddah, Dār al-Sa'ūdiyyah, 1987, p. 125-127, who also was witness to some Christian evangelical expectations, which he ascribed to the influence of the Dağğăl. 
which he identifies as America and Europe]... so the battle of Armageddon is the first of what we are expecting as the beginning of the final tribulations and apocalyptic wars. It will be as we will detail in chapter 3: "the Mahdï" a destructive nuclear battle during which most of the strategic weaponry of the world will perish, and the final word battles afterwards will return back to swords, spears and horses. It is no wonder, therefore, since the unvarying existential law concerning all ancient civilizations is destruction after flourishing, and diminishing after rising, and the civilization of the 20th century has reached the peak of earthly innovation and even speaks of what they call 'Star Wars'". 57

Ğamāl al-Dīn also explores Biblical prophecies. Towards the middle of his book he begins to cite evidence for the idea the end of the world is very soon, between 1999-2000. Although in his later volume, in response to his critics, al-Radd alsiham, he was to revert back to the Muslim material to prove his case, in this initial volume he quotes Matthew 20:1-16, the Parable of the Workers. In short, this parable details a number of groups of people (later identified as Jews, Christians and Muslims respectively) who are hired to do exactly the same work by the master (God) at different times of the day. When at the end of the day each of them receives the same wages, the earlier groups (the Jews and the Christians) complain, saying that the last ones (the Muslims) were only hired just before sunset, and had not put in a full day's labor, and so did not deserve their wages. ${ }^{58}$ Using this parable, he is able to date the end of the world (by calculations tied to the World Day of 7,000 years and assumptions on how that would fit into a "day" based upon 24 hours). It is ironic, and indicative of the state of modern hadit studies that this very parable, in a Muslim version was already quoted in classical works, and he does not seem to be aware of it!5?

Again moving back to Muhammad 'I $\bar{s}$ sà $D^{a}{ }^{-} \bar{u} d$, he is concerned to prove that Muhammad was a prophet using the Biblical sources. He closely follows themes already developed in classical times, such as the verse in Deuteronomy 18:18 "The Lord your God will raise up for you a prophet like me [Moses] from among your own brothers." Since obviously this is a prophecy about the mission of Muhammad (according to the Muslim perspective, it establishes the bona fides of the Biblical material sufficiently for $\mathrm{D}^{-} \overline{\mathrm{u}} \mathrm{u}$ to begin to use it in earnest. ${ }^{60}$ But $\mathrm{D} a \bar{a}$ ūd goes much further and uses extensively apocryphal gospels and Christian Fathers as sources. He is extremely eclectic in his taste, and it is apparent that he is merely trying to find any source which will prove his point. ${ }^{61}$

57 - Ğamāl al-Dìn, 'Umr ummat al-Islām, p. 39.

58 - Ibid. p. 50-51.

59 - A.J. Wensinck, Concordance, Leyden, E.J. Brill, 1936-62, s.v. "qïrāṭ; and see Abū Ya 'là al-Mawṣili, Musnad, Dimašq, Dār al-Ma'mūn li-l-Turāt, 1986, IX, p. 343, X, p. 208-209.

60 - Dā')̄ùd, p. 60-61.

61 - E.g., Dā'ūd, p. 76-82, 114-115, 121, 131. 
Other writers are even more extreme in their pro-Biblical attitude (all the while denying that they have one!). For example, Hišăm Kamäl 'Abd al-Hamìd in his books Haläk wa damär Amrikā al-muntazar and Iqtaraba burüğ al-Masīh al-Dağğal shows his preferences by quoting the Bible at length every time a citation is mentioned, while whenever he cites a badit he merely summarizes it. $\mathrm{He}$ almost never gives his sources in the hadit literature, but he always does for the non-Muslim material. Considering the state of Muslim knowledge of the badit literature, it really should be the other way around. But this state of affairs shows which body of material is the more prestigious.

\section{A harmonizing solution}

Modern apocalyptic is quickly turning into a synthesis between a number of different sources, only one of which is the hadit literature. In certain cases, however, the temptation to delve deep into foreign literature and find answers to problematic issues has been resisted. One of the best examples of this is the apocalyptic fall of Constantinople (modern-day Istanbul). Gamāl al-Din lists this off as one of the signs, especially since it appears (as noted above) to be a necessary precursor of the appearance of the Dajjal. He knows of course that centuries ago Constantinople was taken by the Muslim Ottoman Turks, and that according to the plain logic of the Dajjal traditions, the end should have come in approximately 1460 (seven years after the fall of the city). "... it was the capital of the Ottomans until Mustafa Kamal Atatürk came - that imperialist agent - and abolished the Islamic caliphate at the beginning of the century and established secularism in place of it".

But he has a solution to this problem: the mutual defense pact between Israel and Turkey, together with Turkey's pro-Western policies. When this is coupled together with the training that the two countries' armed forces do together, and the threat of Turkey controlling the water sources of the Euphrates and the Tigris rivers all becomes clear. "The immediate future will reveal Turkey's true face, and then we will say that the Messenger of God said truly 'You will conquer Constantinople...' Yes, they deserve a conquest". ${ }^{62}$

"The Messenger of God said: 'You have heard of a city which one side of it is on the dry land and the other on the sea?' They said 'Yes, O Messenger of God.' He said: 'The Hour will not arrive until 70,000 of the Banu Ishaq will raid (yagzü) it, and when they have come to it, they will camp and not fight with weapons and not fire arrows. [they will say] "There is no God but God!", and "God is great!" and one of the sides will fall down'."63

62 - Ğamäl al-Dīn, 'Umr ummat al-Isläm, p. 74; and compare al-Qawl al-mubin, p. 113-114; Hamzah al-Faqir, Talätah yantazirubum al-' älam, p. 68-69; and Muhammad 'Izzat 'Aríf, Nihāyat al-Yähüd, al-Qähirah, Där al-I'tișām, 1996, p. 191. Ayyūb, Masịh, p. 197 note 32 has a different solution (he of course preceded the Turkish-Israeli alliance): Constantinople is really Rome, and that is the city which will be conquered then.

63 - Ğamäl al-Dīn, 'Umr ummat al-Isläm, p. 75. 
At last here we see a clear example of Muslim interpretation of a badit untainted by any foreign material, but still relevant to the modern situation. As one could expect, Muhammad 'İsà Dā' ūd takes it from there. As he continues on with his scenario of the Mahdi's conquest of the world, he comes to the question of Turkey. According to his view, the rulers of Turkey will refuse to swear allegiance to the Mahdi, and mass to fight him. Dā' $\bar{u} d$ says "... but among the Turks are those who are Muslims, helpers and pure, and long for the day during which everything will return to its origin. Turkey is truly Muslim, but needs a new conquest for God to strengthen it in Islam, after the government of Atatürk the accursed and his allies who have imprisoned Islam into secrecy and left it only in the books and in the mosques". ${ }^{64}$

Other writers also use this tradition, which has proved to be fruitful. Although he has his dates wrong (Constantinople was conquered in 1453, not in 1353 as he says) Manșūr 'Abd al-Hakim, spends quite a good deal of time with the idea of what the conquest of Constantinople means. He is perfectly aware that it has already fallen and that the tradition must be reinterpreted, but does not choose to follow Ğamäl al-Din in his anti-Turk interpretation, even though he knows that Atatürk was a Jew and tried to destroy Islam. But overall, he makes an attempt to allegorize the taking of Constantinople away from the taking of a geographical location to an ideal. Constantinople and the Byzantines represent the temptations of the west which has seduced Islam and lulled Muslims into a deep sleep. The Mahdi will awaken them from this sleep, and lead them to victory, taking Constantinople from anew, and entirely expunging the western foreign influences from the Muslim world.
"They are living in a stupor, drugged, the Christians having drugged them with promises and oil wealth and the soft and carefree life, and the easy life, and going to their lands in order to pleasure themselves in everything that is allowed and forbidden - without any difference between the two of them. The Europeans and American lands are opened for them so that they can spend moneys which came to them easily from the ground, from oil and the riches of the ground, and they have forgotten that they are 'the best nation brought forth to mankind bidding the right and forbidding the wrong' [Qur'àn $3: 110]^{\prime} .65$

Muhammad 'İsà $D a ̄ ' \bar{u} d$ also focuses much more completely upon otherwise unknown Muslim manuscripts to flesh out his scenarios. He is obviously not entirely satisfied with the reliance upon Biblical material, and there is not enough badit to actually base a Mahdi fantasy upon. For him the solution was to (apparently) create new sources. There is no way to know whether these manuscripts really exist or not; most probably they do not, or at least it is unlikely that they say what he says they do. A good example of this sort of tradition is the following:

64-Dā̄ūd, p. 133-134.

65 - 'Abd al-Hakim, p. 23-26 (quote from p. 26); Qur'anic trans. from Majid Fakhry, The Qur'ān, London, Garnet, 1997. 
"The war of the tree and the palm, and the $\mathrm{Ka}^{\mathrm{c}} \mathrm{bah}$ and the Nile towards Syria, the war of nobility to a cup and a humiliated crown this is the prophecy of the messiah of the Lord that the Lord's rightly guided, the tree of life, the tree of light and the tree of the fish, the Lord fights Israel in Egypt, and Egypt fights the Lord heatedly and regretfully. The Lord approaches victoriously to Israel and is angry with Israel, and the anger of the Lord approaches vengeance. The Lord puts Israel to shame, and a king will not kill Israel. The Lord has mercy on Israel, and all of Israel is angry with the Lord. The Lord becomes angry with Israel, and the Egyptian man kills Israel. Israel becomes king in Egypt and the Lord places a new king over Israel. Destruction approaches and a fire in the Sinai... [the manuscript cuts off]". 66

Trying to make some sense of that, one can honestly be glad to leave the whole matter to Dä'ūd's fluent pen, and admittedly throughout the book he seems equal to the task. Yet one would suspect that for someone with an equally vivid imagination, these sort of prophecies could be interpreted in wildly differing manners. It is $\mathrm{Da}^{-}{ }^{-} \mathrm{u} \mathrm{d}$ 's good fortunate that thus far he has had a monopoly over his new contributions to the world of apocalyptic studies.

\section{Conclusions}

Twice during its history Islam has had to confront Christianity intellectually and borrow massive amounts of material from Christian sources: the first being during its formative years and the second during the past 150 years. During both times there has been a problem digesting this material. During the first round it is clear that a vast number of ideas were absorbed in the initial encounter which proved to be ones which caused Muslim theologians a great deal of discomfort. Part of this discomfort stemmed from the absorption of apocalyptic traditions, of which a large percentage ultimately come from Christian sources. However, over the centuries many of these traditions were either excised from the canon (and consigned to the category of $\operatorname{mawdu}^{-} \bar{a} t$ ) or at least commented upon in such a way as to devoid them of all life. These apocalyptic ideas served Islam well for centuries. They provide a satisfactory framework of existence, albeit one of a militaristic and aggressive nature, and give it an acceptable place in human history. The apocalyptic traditions are exciting enough to give life to the faith (providing an outlet for apocalyptically minded groups) and focusing their aggressiveness on areas outside of Islam. It has been Islam's great fortune that the area it chose for apocalyptic centrality, the area of Syria-Palestine, has been the center of conflict for centuries, and has thus created a sense of relevance for these traditions.

66 - Dā'ūd, p. 154; see Amir 'Arab, al-Mahdī al-muntazar: haqiqah um ḩiräfah?, Bayrūt, Dār al-Rasūl al-Akram, 1998 , p. 34-35 tries to pass off an equally ludicrous forgery supposedly

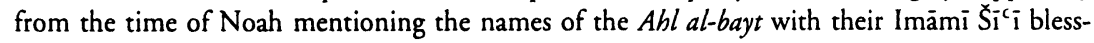
ings. 
Without a doubt, however, this sense of relevance has not sufficed for the Muslim audience during the past 30 years. The hadit literature, in the sub-genre of apocalyptic traditions, which has held uncontested sway over the Muslim imagination for centuries has had to step aside and accommodate new sources of authority. While this has not entirely destroyed the authority of the hadit literature, it has definitely diluted its authority and perceived comprehensiveness. What more could be expected when even those such as Sa ${ }^{c} \bar{i} d$ Ayyüb and Muhammad 'Îsà $D a ̄$ 'ùd, both of whom descry the pervasive western influence in Arab societies, find themselves furthering this satanic influence while attempting to uncover its plots? Even Ğamāl al-Din, who is the last hope of the conservatives (if they could only see it!), cites the Bible and western evangelical Christians as support for the idea that the world is coming to an end rather than deepen his study of his own tradition.

Simply put, the hadit literature has lost its primary defenders simply because of the perceived lack of relevance. Apocalyptists are among the first to feel this because they are so close to the edge of the necessity to constantly up-date and revise their predictions and scenarios, as around them Jews control the world, Muslims are humiliated and defeated, technology leaps and bounds forward, leaving Muslim societies rootless and disconnected, and treaties are signed with the arch-enemy Israel. The apocalyptic traditions available to the Muslim have not been able to provide a framework capable of absorbing these inexplicable changes, and so apocalyptists have taken an easy route. They have taken Christian apocalyptic expectations, raided and dissected them for any material of use to them, grafted on to them whatever can be salvaged from the wreckage of Muslim apocalyptic literature and then produced a scenario. When this is further combined with the anti-Semitic conspiracy theory (itself dependent upon Christian beliefs and history), the hadit is relegated to place number three and is only cited when it is comfortable for the apocalyptist to do so.

The advantages to this method are obvious: the scenario is a powerful and relevant one, and it has obviously grabbed the imagination of many. The disadvantages are just as obvious: in using western methods and sources to attack western civilization, the Muslim apocalyptist is merely furthering the westernization of his culture. Any of his readership who looks at the bibliography will inevitably come to the conclusion that if this is the best that one who would attack westernization can do, then truly any chances for achieving a completely Muslim culture are lost. This is most especially obvious in the disconnected nature of the new apocalyptic scenario, which relies so heavily upon Christian history (and essentially teaches whoever reads this literature a short, albeit paranoid, course in western civilization). The apocalyptist is ignoring those conspiratorial elements of his own culture which could be used, were he so inclined to do so or knew enough about it to actually produce such a product, to build a paranoid but Muslim scenario. It must be added that the tools are all around him, were he but to pick them up. From classical times the idea of a Jewish conspiracy against Islam is well-documented. No apocalyptist, to the best of this author's knowledge, 
has ever chosen to highlight this home-grown paranoid tradition, and to cultivate it into something akin to the anti-Semitic conspiracy theory.

It is unfortunate, therefore, that one must frequently point out the ignorance of the Muslim apocalyptic writer, and his essential arbitrariness as regards his own heritage in the badit. Numerous times, of which the above is only one example, this author has seen traditions or statements cited on the basis of Christian authorities which are cited in classical Muslim tradition as well. It is rare that the Muslim apocalyptist shows any awareness of this fact, and in a very real sense is denying the relevance and worth of his own tradition even as he trumpets the need to return to it and to glorify it. There is a significant divide between his words and his methods, between his conceptions and his sources. It would seem that he is not leading back as it were to normative Islam, but to a synthesis between Islam, Christianity and anti-Semitism. 